\title{
EPISTEMIC RATIONALITY IN ISLAMIC EDUCATION: The Significance for Religious Moderation in Contemporary Indonesian Islam
}

\author{
Senata Adi Prasetia, Hanun Asrohah, Siti Firqo Najiyah, and Syaiful Arif \\ Universitas Islam Negeri Sunan Ampel Surabaya, Indonesia \\ E-mail: smart08senata@gmail.com
}

\begin{abstract}
This article discusses the concept of epistemic rationality in Islamic education and its significance for strengthening religious moderation in contemporary Indonesian Islam. The questions are: (1) How is the conception of epistemic rationality? (2) To what extent is the role of epistemic rationality in Islamic education? (3) How do classical Islamic treasures view the epistemic rationality and its significance for strengthening religious moderation in Indonesian Islam? Afterwards, the theoretical assumption underlying this article is that the strengthening of religious moderation without being supported by epistemic rationality is null and void. This article finds that the passion of reading in Islam processed through epistemic rationality has provided huge contribution for Islamic civilization so that it reaches its golden age. Hence, in Indonesian Islamic education context, strengthening religious moderation must be delivered through epistemic rationality as basic reasoning in understanding religious text and digging the diversity phenomenon in order to avoid radicalism and blind fanaticism. Epistemic rationality must be considered as starting point to build curriculum structure and learning contents that emphasize more on the competency of 'know-how' and 'knowwhy' rather than 'know-what'.
\end{abstract}


Artikel ini mendiskusikan konsep epistemologi rasional dalam pendidikan Islam dan signifikansinya terhadap penguatan moderasi beragama Islam Indonesia di era kontemporer. Pertanyaan yang hendak diteliti adalah: (1) Bagaimana konsepsi epistemologi rasional? (2) Sejauh mana peran epistemologi rasional dalam pendidikan Islam? (3) Bagaimana khazanah Islam klasik (turath) memandang epistemologi rasional serta signifikansinya terhadap penguatan moderasi beragama di Islam Indonesia? Asumsi teoritis yang melandasi artikel ini adalah penguatan moderasi beragama tanpa ditopang dengan epistemologi rasional menjadi nihil dan sia-sia belaka. Artikel ini menemukan bahwa spirit literasi dalam Islam yang diproses melalui epistemologi rasional telah memberikan kontribusi besar bagi kejayaan peradaban Islam sehingga mencapai titik nadirnya (the Islamic golden age). Oleh karena itu, dalam konteks pendidikan Islam Indonesia, penguatan moderasi beragama harus disampaikan melalui epistemologi rasional sebagai penalaran dasar (basic reasoning) dalam 'menelan' teks agama dan menggali fenomena keberagamaan sehingga terhindar dari sikap radikalisme dan fanatisme buta. Epistemologi rasional patut menjadi starting point untuk membangun struktur kurikulum dan konten pembelajaran yang lebih mengaksentuasikan pada terciptanya kompetensi know-how dan knowwhy daripada know-what.

Keywords: epistemic rationality; Islamic education; religious moderation

Received: August 23, 2021; Accepted: December 06, 2021

\section{Introduction}

The Ministry of Religious Affairs of The Republic of Indonesia is recently pointed out the strengthening of religious moderation as an original 'religious' method. Strengthening religious moderation as a moderate religious method requires active involvement of religious educational institutions, especially Islamic educational institutions (Kementerian Agama 2021; Suradi et al. 2021). The objective is to make religious moderation as a turning point to initiate and construct-borrowing Emile Durkheim term-social cohesion (Durkheim 1897; Friedkin 2004; Pahl 1991) to be more intimate and productive for both religious and nationality objective extensively. 
Religious moderation is an ideal goal for Muslims to achieve social cohesion in the midst of westernization, modernization, and industrialization from all directions. For this reason, Masdar Hilmy has assumed that the formulation of Islamic modernism is dynamic. It indicates that the formulation developed by Nahdlatul Ulama and Muhammadiyah is deficient-to say unable-to accommodate the current challenges and demands (Hilmy 2013b). Therefore, in the context of Indonesian Islam, a representative formulation of how moderate Islam can be constructed through rational epistemology is needed (Kamali 2015).

Islamic education, as reported by Sunhaji, has played for a long term as double act. On the one hand, it functions as an enlightening process for Indonesian Islam by providing a sense of moderation. On the other hand, it open ways for students or non-Muslims subjects to receive adequate education (Sunhaji 2017). In this context, Islamic education has playedSunhaji called as-social humanism. In addition, Islamic education has become an effective way of power struggle and social mobilization among Muslims in the centre of socio-political environment. Some recent research studies have showed that the idea of knowledge and education in Islam has shifted from inclusive and rational search to be narrowly focused on religious knowledge (void of rationality) (Kamali 2003; Lane and Redissi 2016; Mikhail 2004; Sabic-El-Rayess 2020; Tamer 2015; Wiktorowicz and Kaltenthaler 2006).

Based on the explanation above, it can be assumed that the strengthening of religious moderation without being supported by epistemic rationality will be null and void. In order to repeat its golden age (Renima, Tiliouine, and Estes 2016), Islamic education must be re-applying epistemic rationality in every learning process to stimulate students' critical thinking and not being trapped in the stagnation of thinking or even involve in radicalism. Hence, this article aims to discuss the concept of epistemic rationality, methodology, and gradation of practical implementation in Islamic education and its significance for strengthening religious moderation in the contemporary Indonesian Islam. This study will be more focused by synthesizing literature from Islamic sources, classical Islamic treasures or Western literature on epistemic rationality in Islam and its significance for strengthening religious moderation in contemporary Indonesian Islam. 


\section{Epistemic Rationality: The Forgotten Tradition}

The term epistemology was first introduced by JF Ferrier in 1854 (Ferrier 1856; Thomson 1964). In Dictionary of Philosophy, Dagobert D. Runes has explained that the word 'epistemology' come from 'episteme' and 'logos/theory' (Runes 2001). 'Episteme' means knowledge, understanding, and acquaintance. Meanwhile, 'logos' is defined as account, argument, or reason described systematically (Al-Kurdi 1992; Anshori 2015; Gazalba 1973; Koesnoe 1997; Steup, Turri, and Sosa 2013; Wijaya 2014). From these two terms, epistemology is then defined as a branch of philosophy that examines the authenticity of understanding, structure, method and validity of science (Kattsof 1996; Runes 2001).

Epistemology has a long history in Western philosophy, starting from ancient Greece to the present along with metaphysics, logic and ethics. These terms are included as one of the major branches of philosophy and almost every major philosopher has contributed to them (Martinich 2021), for instance, the contribution of Plato's epistemology of trying to understand things that should be known well (unlike the true opinion) for those who knew.

From another perspective, epistemology is often referred to as philosophy of science. Anton Suhono has defined epistemology as a theory about the nature of science, which is a branch of philosophy that reviews human reflection on reality (Amin 1983). As a term, episteme is related to the archaeology idea of knowledge by a French post-structuralism philosopher, Michael Foucault (Abdullah 2017; al-Jâbirî 2003; Foucault 2020; al-Jâbirî 1995). Episteme, in Foucault's point of view, means "base, archive, principle, or compass to determine direction" in the historical context, especially the history of thought. Foucault uses episteme term to show a presupposition, principle, and condition of certain possibility and approach to form a system that determines perspective and observation (Anas 2018; Bertens 2006). Therefore, each period has a different 'episteme' according to the context and the effort to explore the episteme that determine the direction of a certain space and period defined as knowledge archaeology (Foucault 1970, 1972; Guedon 1977; Foucault 1970). The fact said that episteme is relatively new, but its emergence is as old as any field of philosophy (Woleński 2004).

From several terms explained above, it can be identified as technical concept of epistemology such as reason (Immanuel Kant) (Kant et al. 1952), episteme (Michael Foucault) (Foucault 1972), and scientific paradigm 
(Thomas S. Kuhn) (Kuhn 2012). Nevertheless, contemporary Islamic thinker also use similar terms such as al-khitâb al-dînî (Nașr Hâmid Abû Zayd) (Abû Zayd 1994), al'aql al-Islâmî (Mohamed Arkoun) (al-Fajjârî 2005; Arkoun n.d.), and al'aql al'arabî ('Âbid al-Jâbirî) (al-Jâbirî 1991, 2000). These terms certainly have its own variations and distinctions even though all of them are indicated that knowledge has epistemology system as its basis.

Thus, epistemology is a branch of philosophy that examines questions that 'disturbing the establishment' of general human understanding in order to achieve optimal goals of human cognition, which includes knowledge, justification, explanation, understanding, and wisdom. Epistemology is different from other two branches of philosophy that are metaphysic (questions related to existence, reality and ontology) and ethics (about moral values and right action). Some epistemological questions that can be developed by experts include: (1) What are knowledge, justification, explanation, understanding, and wisdom? (2) Can epistemological goal be achieved? If yes, what are the steps? (Buckland and Chinn 2015; Carter and Littlejohn 2021) Questions like these really intrigue humans to use their cognition as optimal as possible. In short, epistemology is a theory of knowledge that discusses how to obtain knowledge from the object of thought (Qomar 2005).

Afterwards, the following term discussed here is 'reason' which derives from Ancient Greek (Britannica 2021; Society for the Diffusion of Useful Knowledge (Great Britain) 1836). Modern interpretation interpreted it as computation or reckoning or calculation (D. E. Smith 1923). In the Middle Ages, reason-by writers of this century is defined as proportion to show the ratio and proportionality for equality of ratios (Wentworth, Smith, and Harper 1922). Thus, if it is combined, epistemic rationality is an epistemology based on reason (sensory or hissî) (Nasution 1995; Qomar 2005), and some assumed it as things based on belief (al-yaqin) (Wijaya 2014). According to Tsuroya Kiswati, there is actually a figure that deserves to be acknowledged as the founder of rational theology in Islam, namely alJuwaynî (d. 478 H/1085 AD) (Kiswati 2015).

Aksin Wijaya has divided two terms of belief (al-yaqîn) in the context

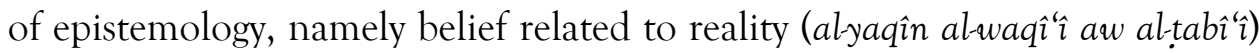
(al-Kurdî 1992) and scientific beliefs (al-yaqîn al'ilmî) (Wijaya 2014). This is in line with Mujamil Qomar's opinion except he divided the method to 
achieve knowledge into two: rational and empiric (Qomar 2005). Rationalism acknowledges three kinds of truth including empirical-sensual, empirical-logic, and empirical-ethical truth (Qomar 2005). The first rationalism place in the lowest level, while the third rationalism place in the highest level. This kind of recognition indicated that the nature of rationalism still prioritizes tools to gain knowledge, yet sensory experience is not ruled out.

In this context, there are three kinds of main proposition in epistemic rationality including belief in the existence of truth (objects), humans are believed to know that truth, and reason is believed as a tool to find knowledge. An individual who stands up for epistemic rationality will believe that truth is found through reason before observation. For him/her, mind has stored truth without concerning to the reality outside (Bertens 1998). Nonetheless, epistemic rationality will not automatically neglect empirical experience, but using empirical experience as mind stimulus and as a 'stamp' of truth achieved by reason (al-Kurdî 1992; Wijaya 2014), once it used to catch sensory object. In epistemology, the sensory result is not yet called as knowledge since it is merely phenomenon, thus it is needed to be processed in mind (Wijaya 2014), then it can be called-as Geertz saidneumena (meaning) (Geertz 1996). Geertz has called this methodology as thick description method (Geertz 1973). Henceforth, epistemic rationality belief in a priori truth (Baehr 2012; McGinn 1975; Tahko 2011; Williamson 2013) as one and only truth, yet a posteriori is not being neglected. This is become a reason why parameter for epistemic rationality is quite mathematic or impossibility of denying something that is certain, and vice versa.

\section{Epistemic Rationality Approach}

Reason or mind is defined as fundamental source of knowledge in Islamic education start from elementary to higher education. Historical evidences have showed that the peak of Islamic golden age was initiated and inspired by massive use of reason (Bennison 2014; Gordon 2011; Lim and Khan 2016; Renima, Tiliouine, and Estes 2016). Reason is not merely as intermediary (wasilah) to chase or gain knowledge, but it can be used for further study development (Hery 2008). Wâșil ibn 'Ațâ' (the founder of rationalist madhab, Mu'tazilah), for instance, prioritizes rationality in studying all sciences (Al Fârûqî 1968; Khan 2017), then al-Ghazâlî has experienced 'prolonged turmoil' due to series of hundred questions, hence 
he put all of his intellectual adventure in a work entitled al-Munqîdh min alDalal (al-Ghazâlî 1967). These two great Islamic indicate that epistemic rationality is the entry point for understanding and processing religious text or established belief so as to avoid fanaticism.

Moreover, there are three kinds of epistemic rationality approaches used as analysis tools in understanding religious text and testing the knowledge's validity, namely curiosity/inquisitiveness, skepticism, and inductive conceptualized by Rene Descartes as basis for thinking rationally.

First, inquisitiveness approach. Inquisitiveness is described as a character which makes Muslim scientists get high appreciation in knowledge development in the classical Islamic era (Inquisitiveness 2021). The description of classical Islamic higher education requires curiosity in various fields, including (1) Islamic education is intended to expand knowledge and spread Islam, (2) freedom for students to choose lecturers or scholars who are qualified in their fields. Students will leave and switch to other lecturers if they are deemed not to have fulfilled their curiosity, and (3) the potential for reasons and critical reasoning is highly optimized in the teaching and learning process (Dodge 1962).

The above reality shows how strong the tradition of inquisitiveness is in teaching and learning process in Islam. Pervez Hoodbhoy has explained that once Gundeshapur as the intellectual centre of the Sassanid Empire in Persia fell to Muslim armies in the $7^{\text {th }}$ century. They found 'treasures' used as Greek's learning material in the form of manuscript, "There was a curiosity during those times which lead to the introduction of science in Islam for the first time." He stated, Ibn Rusyd's (Averroes) name is cited on Massachusetts Institute of Technology (MIT) building along with the names of other famous scientists such as Isaac Newton, René Descartes and Gottfried Wilhelm von Leibniz. He also said that "Averroes was the first person who brought sharp and fast scientific rationality, therefore he is called as the Intellectual Father of Renaissance" (Hoodbhoy 2013).

The development of discourse and scientific discoveries in Islam started from curiosity. It resulted in an intellectual breakthrough, personality and brilliant publications which became such a pride of Muslim civilization for centuries and inspire the West who is now "enjoying" the legacy. Therefore, Muslims need to detach from 'taken for granted' mind-set and/or several basic contradictions which still oppose Islam and science. Surely, it is considered to be counterproductive. Hoodbhoy is being asked about Muslim contribution over last 900 years, but he replied, "Nothing. 
With the death of curiosity, the Muslim civilization fell from the peaks of greatness" (Hoodbhoy 1991).

Second, skepticism approach. In epistemology, there are three main questions: (1) What is knowledge? (2) Can human have knowledge-and if so, what is the scope? (3) What is the source of knowledge? (Greco 2017; Moser and Nat 1978). Skeptical individual will answer the second question from negative and pessimistic point of view. On the other words, skeptical individual will deny if human is able to know anything or that the power of knowledge is very limited.

Skepticism in classical Islam reveals that doubt is an integral part of scientific life nowadays. Since ancient times, skepticism is mostly based on arguments to doubt the reliability of various sources of belief. The importance of 'skeptical arguments' is not merely because of the offered challenges to change the possibility of acquiring knowledge, but also because it helps to deeply understand the knowledge. In this case, skeptical arguments have become a major concern of epistemology, as Laurence Bonjour noted: "...if the skeptics did not exist, it could be argued that serious epistemologists must find them" (BonJour 2008). Although the history of skeptical argument goes back to ancient Greece, Descartes is often considered as the first philosopher to articulate and formulate a new and modern version of skeptical argument. In this case, we will not discuss what or how new Descartes's skeptic argument is; instead, we will focus on the pre-Cartesian version (Fatoorchi 2013). In this context, we would like to address the extraordinary skeptical debate played by two earlier Persian philosophers or theologians: al-Râzî (Fakhr al-Dîn al-Râzî, d. 544/1149606/1210) and al-Ṭ̂sî (Naṣr al-Dîn al-Ṭûsî, d. 597/1201-672/1274) (Cooper 1998; Dabashi 2020; Griffel 2007; Pourjavady 2000). Both are prominent figures who have had a great influence on Islamic philosophy and theology (al-Râzî 1984; Landesman 2002).

Furthermore, there is one epistemological principle that is guided by this approach to skepticism, namely the epistemological Sufism by alGhazâlî, "Doubt can lead someone to the truth. A person who does not doubt, he does not have reason. A person who has no reason, he will not be able to see at all. A person who cannot see, how can he possibly know? Instead of awareness, it is the darkness and digression that he will obtain" (al-Ghazâlî 1964; Wijaya 2014).

This essential statement indicates that al-Ghazâlî was very skeptical in thinking in the early days of his knowledge journey. By being doubtful, only 
can one find a convincing truth (al-Ghazâlî 1967). It is not doubt itself that leads to the valid truth, but at least it will stimulate someone to think. In the context of Islamic education, this kind of thinking is very necessary. Islam teaches, "walâ taqfu mâ laysa laka bihi 'ilm" (do not follow something you don't know). Islam encourages the Muslims not to settle for knowledge from a single source. They must look for other sources to test the validity of their knowledge even though they have to travel a very long way as exemplified by the earlier scholars.

Third, inductive approach. It is a process of acquiring knowledge through concrete activities in which the truth is proven through empirical material testing both in the laboratory and in real life. Thus, inductive reasoning does not depart from a general theory, but empirical data in the field which is then reflected and 'processed' by researchers towards a general theory (Engel and Schutt 2014; Hilmy 2013). Iqbal emphasizes that Islam provides a very wide space for the inductive spirit in the process of seeking scientific truth. He states, 'the birth of Islam is the birth of inductive intellect' (Iqbal 2013). The Islamic Golden Age refers to a period in the history of Islam, traditionally dated from the 8th century to the 13th century, during which much of the historically Islamic world was ruled by various caliphates and science, economic development, and cultural works flourished. This period is traditionally understood to have begun during the reign of the Abbasid caliph Harun al-Rashid (786-809) with the inauguration of the House of Wisdom in Baghdad, where scholars from various parts of the world with different cultural backgrounds were mandated to gather and translate all of the world's classical knowledge into the Arabic language.

So, we would like to demonstrate that Iqbal's statement (i.g the birth of Islam is the birth of inductive intellect) at a glance as explained above, seems very apologetic when the achievements of Islamic civilization are at their higher point. However, at the same time, the history of Europeans from the time of the Greeks to the early 17th century is a story about the absence of experimentation and observation and the idolatry of reflective thought and reasoning (Hilmy 2013; Qadir 1988). Therefore, deductive reasoning, although very useful in the early stages of human civilization, is proved to be a stumbling block for the development of pyhsic science that relied heavily on these two scientific instruments are inductive reasoning and epistemic rationality. As Amra Sabic El-Rayess theorized that the idea of knowledge and education has shifted in Islam from an inclusive and 
rational search for all knowledge to a narrowed focus on religious knowledge, void of rationality (Sabic-El-Rayess 2020).

In the perspective of religious and/or Islamic sciences, the actualization of the inductive approach is clearly a challenge considering that religious sciences are genealogically born from the deductive paradigm. If Quran, for example, is the product of God revealed deductively, then science is the result of human's thought done inductively. This means that the Holy book encourages gaining knowledge through deductive paradigms and methodological tools, but it is in different case. However, in the process of reviewing the religious sciences, they still prioritize deductive paradigm as a tool to disseminate 'good news' and 'rescue missions' to all mankind (Hilmy 2013a). It is confirmed an understanding that the existence of the Holy book is not in position to be integrated into its truth since it contains axiomatic truth which is not a subject to rational truth as a result of human's thought. In any religious tradition, the truth spirit contained in it remains the same that is deductive truth.

This reality faces a more serious challenge when the religious truthborrowing the terms from Barger and Luckmann-is externalized, objectified and internalized in scientific inquiry perspective (Berger and Luckmann 1991). It is due to the truth parameter which does not only adopt a deductive paradigm, but also an inductive paradigm. Even, the development of science and social adopts the inductive paradigm as its main tool (Hilmy 2013a). In fact, the deductive approach still occupies an important role in the development of science though it only works in certain scientific subfields. Recently, inductive methodological approaches and tools have become a turning point which is able to direct the black-white side of science development (scientific enterprise). This fact is strengthened by the tradition of Western empiricism and positivism which penetrates the discourse of religious and/or Islamic sciences (Abdullah 1996).

Moreover, the fundamental of inductive approach is basically based on the Cartesian paradigm. It examines and unravels the reality of life based on the law of cause and effects. This paradigm is attributed to Rene Descartes, a great French philosopher, who pioneered the birth of modern Western civilization (Hilmy 2013a). This paradigm is a representation of rationalists' victory in the front stage (Goffman 1978, 2002) of science and is only a subject to empirical evidence which is able to thwart the rationalist thesis (Cottingham 1990). At first, this approach runs deductively as a result 
of Aristotelian-deductive method tradition's dominance. This school is based on an adage, "cogito ergo sum/I think therefore I am" (Scheibe 2001).

If it is contextualized with the Islamic education reality, this approach framework will produce a curriculum structure which emphasizes the creation of know-how and know-why, rather than know-what. Nevertheless, the curriculum structure and learning content must appreciate the development of-borrowing the term from al-Jâbirî-burhânî reasoning which is the basis of inquiry knowledge, both the basic and the applied reasoning levels (Ahmad 1989; Hilmy 2013a). It must be admitted that the structure of the current Islamic education curriculum appreciates more on the development of burhânî and 'irfânî reasoning, rather than only burhânî (alJâbirî 1991). In this context, the introduction of basic principle (basic reasoning) is very relevant to be conducted.

\section{The Position of Epistemic Rationality in Islamic Education}

In Western philosophy, rationalism views the reason as the main source and the knowledge validity. The reason structure has a set of inherent logical structures. For rationalists, truth can be understood directly by the intellect (Fedyk and Xu 2018). Even in ethics and metaphysics, the role of reason is so fundamental that anyone who denies it is the same as abandoning the truth. Borrowing Michael Rescorla's mind frame (Rescorla 2013) which stated that the epistemic rationality position in Islamic education consists of at least five things, namely:

First, epistemic rationality is normative. Thus, it plays a role in regulating a certain set of logical (Bicchieri 2005; Merriam-Webster 2021), statistical or inferential principles in order to determine how one should think according to certain established standards. In the context of Islamic education, epistemic rationality is used to understand and process dogma, hence it can be implemented at the praxis level.

Second, epistemic rationality is descriptive. It is not just following the rules of rational thinking, but this epistemology serves to portray and describe how a person actually thinks about a particular object (MerriamWebster 2021; English 1976). Descriptive here means a complete description of the objects' points of views so as to avoid the practice of blind fanaticism.

Third, epistemic rationality is constitutive. As constitutive, it corresponds to some regulatory ideals of rationality (Arruda and Boyce 
1993; (Merriam-Webster 2021). At least in some part, it is exactly as what have been thought (McDowell 1998). The point is epistemic rationality has sovereignty in determining the validity of the object's truth, as well as establishing it as truth or error. In the context of Islamic education, this type of epistemic rationality is certainly able to have a strong resonance in moving the mindset and paradigm of students and adults' thinking. Islamic education as a producer of scientific knowledge confirms a constitutive rational epistemology in order to avoid knowledge whose validity is not yet clear.

Fourth, epistemic rationality is critical thinking. Some Islamic educational institutions in Indonesia, including higher education institutions, tend to think in a deductive-normative way (Merriam-Webster 2021; Elder and Paul 2020; Hilmy 2013a; Hitchcock 2017). What is meant by deductive-normative is a way of thinking that places normative aspects above inductive-rational and critical explanations. In explaining something, for example, students are faced with the causality of a problem based on the law of cause and effect. However, the text or religious norms have becometo borrow the term from Talal Asad-a discursive tradition (Asad 2009). The implication is this type of thinking tends to make the students' brains lazynot to say blunting-to seek and find causal links behind every life phenomenon that they encounter. In this context, Islamic education needs to reposition critical reasoning as the basis of epistemic rationality in every lesson.

Fifth, epistemic rationality is creative. Creative thinking always starts with critical thinking, namely finding and creating something which did not exist before (Merriam-Webster 2021; Paul and Elder 2019; Webster 1990). Creativity is an important asset for humans nowadays. It is useful to realize an attitude or character that is open, inclusive, respecting various opinions and the ability to translate and describe ideas as well as the ability to know oneself realistically. Borrowing Cardinal Newman's formulation, as quoted by Deborah L. Rhode, the creative aspect as the development of epistemic rationality aims to develop intellectual skill and increase the capacity of reasoning (Hilmy 2013a; Rhode 2006).

In the context of Islamic education, creativity as the basis of epistemic rationality does not only focus on researching and scientific thinking, but also on a whole series of scientific activities that uphold noble values, creativity and innovation in the academic world (Gopnik and Bonawitz 2015; Ringer 1992; Walker, Gopnik, and Ganea 2015). Thus, the five roles 
of epistemic rationality become the starting point to reaffirm Islamic education character in its golden age. It aims to avoid psychological confusion in responding to whatever comes next, especially with regard to religious traditions in the midst of increasingly complex challenges of modernization, industrialization and digitalization.

\section{The Significance of Epistemic Reality for Religious Moderation}

At the substantive level, any religious teachings that are explicitly or implicitly contained in the holy texts have never legitimized the behavior of hating certain religious people, or even fighting and killing each other. Moreover, if religious people rethink the scripture (W. C. Smith 1989) by making epistemic rationality as Islamic discursive tradition (Asad 2009), the core elements of every religion always teach salvation, peace (salâm), sharing love (philanthropy), and tolerance (al-samhah).

In the formulation of the most basic revelation, the essence of religious teachings revealed by God to the world in a transformative way aims to renew the morality of human beings, who are no longer able to interpret the dimensions of their own humanity, which in Islamic terminology is called ignorant people (umat jahiliyah), to be more civilized (Hilmy 2008). It is in this context that epistemic rationality finds its significance. In the era of an abundance information, there is no other choice for religious education, especially for the strengthening of religious moderation echoed by the Ministry of Religious Affairs recently, except to revitalize its role in balancing the affirmation of religious identity and nurturing the multicultural community. Borrowing Amartya Sen's construction in his work, Democracy as Universal Value (Sen 1999) which Masdar Hilmy also quoted in Pendidikan Islam dan Tradisi Ilmiah (Hilmy 2013a), epistemic rationality has significance in three roles.

First, it is an intrinsic role. It means that epistemic rationality is able to grow and strengthen the intrinsic values of collective life to ensure that each of knowledge acquired has passed a series of validation and qualification tests so that students are not hesitant to determine and take a stand (Moller and Deci 2014; Ryan and Deci 2000). For example, there is a religious moderation believed by a certain group who scorns another group and is contrary to the teachings of the holy text and its rationality. Therefore, students can criticize and counter it by not getting involved in their ideology. Nevertheless, educational institutions from elementary to 
high level must be good at exploring constructive-productive values, and do not focus merely on destructive-apologetics for the basic potential development to be the whole human being. It is actually counterproductive if educational institutions, curriculum structure and religious moderation content precisely erode and eliminate human values. In this kind of role, students must be educated as homo quarens in every activity of religious moderation (Feldstein 1978).

To realize this role, religion is still needed. Religious education is responsible for exploring the intrinsic values of humanity through its most authentic sources such as scriptures and universal values, as well as local wisdom. All acts of discrimination, violence, sabotage, and even murder cannot be justified by religion. The orientation, curriculum structure, and religious education content-including religious moderation-must be attached to the religious liberation mission to create the real human beings who appreciate collective life and human values.

Second, it has the instrument role (Hirose and Olson 2015; Kelly 2003). As an instrument, epistemic rationality only plays a role in delivering students to become real human beings by exploring-in religious language it is called-fitrah (nature) within themselves and being externalized, objectified, and internalized again through real life praxis (Prasetia and Najiyah 2021). In this context, educators need to realize that fitrah is an integral part of human personality. Likewise, the need for knowledge is the same. In fact, knowledge is not just a matter of belief but it is a rationally correct belief (afalâ ta'qilûn, afalâ tatafakkarûn and so on). This kind of nature must be encouraged and moved into positive energy in everyday life.

Unfortunately, what happens in our society is the opposite. They perceive education as a goal and not a tool. The implication is that education does not have neumena (meaning) (Geertz 1973) and any significance to overcome the various problems faced by mankind, especially students. Even there is a tendency that epistemic rationality and religious moderation are part of the problem itself. Precisely, the presence of education through epistemic rationality does not reduce and provide solutions, but aggravates the problems. In brief, epistemic rationality exists not for the sake of education, but for all human beings who carry out educational activities. In fact, epistemic rationality actually plays an instrumental role in delivering someone's understanding to respond and read religious holy texts wisely. 
The third role is constructive (Steffe and Gale 1995). In the context of religious moderation, epistemic rationality takes part in building a collective committed loyalty to live together in diversity. The phenomenon of violence in the name of religion and a series of suicide bombings resurfaced and threatened the national identity of this country (CNN Indonesia 2021). These various actions have become an iceberg phenomenon that must be addressed as an alarm for this country sustainability. Furthermore, if it examined carefully, an act series of fundamentalism, radicalism, terrorism and so on indicate the fragility of Islamic education in spreading the religious moderation values.

Indonesian's socio-cultural interactions and interrelationships are still filled by suspicion, prejudice, and even hatred between fellow citizens. If this nation-especially its educational institutions-does not implement epistemic rationality in the curriculum structure and religious moderation content, the mainstreaming of religious moderation that has been promoted is just like a myth and did not live up to the expectation. Therefore, in order to increase religious literacy, it is important to mainstream rational epistemology to be voiced through digital spaces. In the era of disruption, the understanding of society and students towards scattered religious narratives tends to be biased and counterproductive. The implication is that some people perceive the religious narrative with excessive fanaticism that leads to exclusivity, extremity, and even worse, terrorism. Some other people have crossed the boundaries so that they interpret the holy texts excessively. In addition, there are also those who deceive God's words into a message that is full of conflicts of interest.

In this context, re-reflecting epistemic rationality as an intrinsic, instrument, and constructive role in interpreting, receipting and objectifying God's message in the midst of the national issues' complexity is a necessity. Through the world of Islamic education, national identity and religious moderation value can be taught through epistemic rationality therefore when they grow up, each individual is expected to understand and actualize the values of collective life that are full of appreciation and constructiveness.

\section{Religious Moderation in the Frame of Epistemic Rationality}

The spirit of epistemic rationality in Islam is actually reflected in the words of the Prophet. Iqbal has said that the search for a rational basis in Islam can be traced starting from the Prophet Muhammad himself (Iqbal 
2013). He always said a prayer, "God! Grant me knowledge of the ultimate nature of all things" (al-Hujwirî 1976; Nûr al-Dîn "Abd al-Raḥmân IbnAhmad Gami and Whinfield 1906; Rumi 1994). His other words proclaim the dialogue between Mu'âdh ibn Jabal and the Prophet. When Mu'âdh ibn Jabal was the qâdı̂ (judge) in Yemen, the Prophet asked, "If a legal case is brought before you, how do you decide it?" Mu'âdh replied, "With the book of Allah." The Prophet replied, "How if it is not found in it?" Mu'âdh replied, "With the sunnah of the Prophet." The Prophet asked again, "How if there is not the answer in both?" Mu'âdh replied, "I will do ijtihâd in earnest" (Weiss 1978).

The institutionalization of epistemic rationality as a form of ijtihâd becomes a necessity in analyzing religious messages, then, its presence can be sâlih li kulli zamân wa makân. It must be admitted that the words "moderate" and "moderatism" are a conceptual nomenclature that is not easy to define (Hilmy 2013b). It is due to its meaning becomes a debate among different religious circles and scholars, depending on who defines it (Esposito 2005). Instead of conceptualizing a fit definition of moderation, the concept of moderation actually serves as an obstacle that attracts public debate among Muslims.

In fact, the term 'religious moderation' is not well known in classical Islamic discourse. However, its implementation refers to the use of several Arabic words as conceptualized by Nahdlatul Ulama, namely al-tawassut (moderation), al-qist. (justice), al-tawâzun (balance), al-i'tidâl (harmony) and tasâmuh (tolerance). Some excerpts of the term are used by Muslims to mean a non-violent religiosity mode in the Islamic tradition. Since the word "moderation" is often understood subjectively and exclusively by many people, it invites controversy and subjective bias. The most important thing is it is never neutral from the intervention of political and economic interests.

Controversy about the meaning of moderation and diversity of Indonesian Muslims in the era of disruption that is increasingly paradoxical to the teachings of a peaceful and moderate Islam, makes the Ministry of Religious Affairs set policies to re-mainstream a moderate religious perspective or religious moderation. The Ministry of Religious Affairs then issued a regulation for the establishment of the House of Religious Moderation (Rumah Moderasi Beragama), which is expected to be the locomotive of the religious moderation movement in Islamic universities in 
order to convey the message of a peaceful and tolerant religion. There are several strategic and administrative steps to implement religious moderation academically; one of the implementations of which is the development of studies and academic scientific traditions that are critical and respect other groups or opinions (Suharto 2019).

In this context, we view that the embedding of a religious moderation curriculum must be based on the development of individual critical reasoning in reading religious texts and responding to the spread of religious narratives in the digital space. So, the implementation of rational epistemology in the curriculum of religious moderation at the higher, upper, secondary, and basic levels of education is not a figment or an unfounded discourse, but a necessity because the various prerequisites and modalities needed are already available. The prerequisites and modalities include, among others, the social modalities of the pluralist and tolerant Indonesian society, the intellectual modalities of qualified human resources, and the cultural modalities and language modalities as a legacy that must be maintained and harmonized so that it becomes a beautiful orchestra. These modalities act as underpinning values in mainstreaming religious moderation in Indonesia through rational epistemology.

Therefore, all religious people agree that the Holy book have a significant role in constructing, patterning the collective consciousness and behavior of the community. In the landscape of social-humanities sciences, this theoretical construction is often referred to as the school of culturalism' which views culture-along with its worldview-as a determining factor in the society design. It means that sacred texts or weltanschauung guide and direct society. The dynamic dialectic between these texts is always filled by new adaptations to the demands of the times. It is conducted by some elite circles through re-translation and renewal of its worldview which is perceived as outdated. It is in the midst of this dynamic that dissensus and dissonance often emerge in widespread conflicts.

From the lack of this culturalism school, epistemic rationality tries to fill its "emptiness" space hence it is not trapped in a singular view, but rational works that are more plural. In this framework, the phenomenon of human religiosity can be approached. The differences in readings of the sacred texts reality among religious people cannot be eliminated, since the differentiation is the right of every individual that is guaranteed by law, even transcended by religion. What is needed is how to prevent the 
difference in reading from becoming a pile of dry hay that is vulnerable to being burned by ignorant hands for the sake of momentary interests.

In Islam, clustering the understanding of several verses of the Quran, which has been suspected to be the trigger for the emergence of hatred interpretations among religion, also needs to be done. The basis of the thinking is simple, "God does not want the annihilation of certain religions through the presence of Islam" (al-Baqarah [2]: 213). Thus, the meaning of the verse "for you is your religion, for me is my religion" (al-Kâfirûn [109]: 6) must be confirmed with the verse before, in addition to being adapted to the spirit of the space and time context (asbâb al-nuzûl). In this case, the word 'your religion' (dinukum) is used to refer to the religion of the ignorant people when they tried to stop the preaching of Prophet Muhammad (Hilmy 2008). Besides, the understanding of infidel and gender terminology in the Quran perhaps can be exemplified as an understanding that tends to centrifugal movements (Asrohah and Idayatni 2020; Hilmy 2008; Redfield 1955). In the religion terminology, the word kafir (which is synonymous with nonbelievers) is contradicted with the word Muslim (believers). However, in its historical trajectory, the use of these two words has deviated with the emergence of the Islamic exclusion symptoms from other religions. The simplification is that infidels are interpreted as those who are not Muslim, therefore they must be suspected and fought if necessary.

In another example, there are a number of verses of the Quran that are the cause of hatred among the Abrahamic religions (Judaism, Christianity, and Islam) (Hughes 2012), including Q.S. al-Baqarah [2]: 113 and 120, Q.S. al-Nisâ' [5]: 48, 51 and 52. However, it cannot be denied that Islam is rahmatan lil âlamîn, a religion of peace, whose presence did not erase the previous Abrahamic religions, but strengthened their theological mission (Hilmy 2008; Iman 2020). In addition, if it is related to the reasons for the revelation (asbâb al-nuzûl) of the verse, the validity of the "antagonist" verses above have its own context of space and time. These verses cannot necessarily be used as moral-ethical references throughout history to address other religions outside of Islam, especially to justify inter-religious conflicts. Because the truth contained in these verses is local and particular, not universal and eternal.

In this context, the Quran has the dimensions of "present" and "herein" or-in Fazlur Rahman's terms-a very strong double movement in every span of Muslim history (Rahman 2009). The verses that are often 
referred to as ammunition for hatred and inter-religious conflicts are basically not within the framework of destructive reasoning, namely to end the existence of religions outside of Islam and its adherents. Therefore, the hatred that arises among religious people is actually created by the history of the struggle between them, not by the scriptures.

To understanding this case, the reference to the 'provocative' text substance must be clarified in advance according to the spirit of context. This is where epistemic rationality plays an important role in rethinking the structure that was initiated by Wilfred C. Smith in order to analyze the scriptures proportionally. Furthermore, Smith poses a challenge to be able to not only teaches the correct biblical text, but also how the Bible has given meaning to the lives of Jews and Christians since it became the 'Holy Book' (W. C. Smith 1971). In this context, the degree of moderation and application of the religious moderation attitude must be organized in an epistemic rationality. It is one of the maturing perspectives of religious people towards the sacred texts reality to be imperative. Hence, religious literacy, which is graded, simultaneous and becomes a populist phenomenon as well as non-elitist, is created.

\section{Conclusion}

Epistemic rationality occupies an important position in Islam. Islam provides a very wide space for epistemic rationality in the process of seeking scientific truth. The decline and fall of Islam at Baghdad in 1258 were historical episodes that did not provide space for epistemic rationality in the process of developing science. Also, the history of Europe from Greek times to the early 17th century was a story about the absence of epistemic rationality and the idolatry of reflective thought and reasoning.

As explained in this article, there are many ways and approaches to achieve an epistemic rationality blue-print that is more detailed and easy to apply. It is time for Indonesian Muslims to prove to the world that they have an authentic version of epistemic rationality that is internally driven and sourced from the scriptures, universal values and local wisdom. Indonesian Islamic education must prove that the concept of epistemic rationality is not a myth, but a grounded reality. In this context, the phenomenon of 'Muslim identity card' or 'internal conversion' that occurs in moderate Muslims which become radical Muslims must be understood as a serious strike for moderate Muslims who are not aware of formulatinge an Islamic moderation blue-print become more established. Therefore, 
strengthening religious moderation through epistemic rationality must be re-applied in every teaching and learning process in order to stimulate students' critical reasoning so that they are not trapped in stagnation of thinking, and fall into and engage in radicalism. The principle of good moderation must reflect committed loyalty in order to uphold the Islamic normative values without losing its civilized character. It is time for Islamic education to emerge as the champion of moderate Islam in Indonesia with epistemic rationality as its underlying.

\section{References}

Abdullah, Muhammad Amin. 1996. Studi Agama: Normativitas Atau Historisitas?. Yogyakarta: Pustaka Pelajar.

Abdullah, Muhammad Amin. 2017. "Islamic Studies in Higher Education in Indonesia: Challenges, Impact and Prospects for the World Community." Al-Jami'ah: Journal of Islamic Studies 55(2): 391-426.

DOI: https://doi.org/10.14421/ajis.2017.552.391-426.

Abû Zayd, Nașr Ḥâmid. 1994. Naqd al-Khitâb al-Dînî [Critique of Religious Discourse]. Cairo: Sina li al-Nashr.

Ahmad, S Imtiaz. 1989. "Islamic Perspectives on Knowledge Engineering." In IIIT, 73.

Al-Karasneh, Samih Mahmoud, and Ali Mohammad Jubran Saleh. 2010. "Islamic Perspective of Creativity: A Model for Teachers of Social Studies as Leaders." Procedia-Social and behavioral sciences 2(2): 412-26. DOI: https://doi.org/10.1016/j.sbspro.2010.03.036.

Amin, Miska Muhammad. 1983. Epistemologi Islam: Pengantar Filsafat Pengetahuan Islam. Jakarta: UI Press.

Anas, Mohammad. 2018. Rekonstruksi Epistemologi Ilmu Pengetahuan. Malang: Universitas Brawijaya Press.

Anshori, Isa. 2015. "Kritik Epistemologi Islam dalam Islamologi Terapan." Teosofi: Jurnal Tasawuf dan Pemikiran Islam 5(1): 107-38.

DOI: https://doi.org/10.15642/teosofi.2015.5.1.107-138. 
Arkoun, Mohammad. Qadâyâ fî Naqd al-Aql al-Dînî: Kayfa Nafhamu al-Islâm al-Yawm. Dâr al-Ṭâli'ah.

Arruda, Ellen M, and Mary C Boyce. 1993. "A Three-Dimensional Constitutive Model for the Large Stretch Behavior of Rubber Elastic Materials." Journal of the Mechanics and Physics of Solids 41(2): 389-412. DOI: https://doi.org/10.1016/0022-5096(93)90013-6.

Asad, Talal. 2009. "The Idea of an Anthropology of Islam." Qui parle 17(2): $1-30$.

Asrohah, Hanun, and Sari Idayatni. 2020. "In Search for Gender Equality in Rural Madrasas of Malang Raya." Journal of Indonesian Islam 14(2): 387-406.

DOI: https://doi.org/10.15642/JIIS.2020.14.2.387-406.

Baehr, JS. 2012. "A Priori and a Posteriori." Internet Encyclopedia of Philosophy. https://iep.utm.edu/apriori/.

Bennison, Amira K. 2014. The Great Caliphs: The Golden Age of the 'Abbasid Empire. Yale University Press.

Berger, Peter L, and Thomas Luckmann. 1991. The Social Construction of Reality: A Treatise in the Sociology of Knowledge. Penguin Uk.

Bertens, K. 1998. Ringkasan Sejarah Filsafat. 15 edition. Yogyakarta: Kanisius.

Bertens, K. 2006. Filsafat Barat Kontemporer Jilid II: Prancis. Jakarta: Gramedia Pustaka Utama.

Bicchieri, Cristina. 2005. The Grammar of Society: The Nature and Dynamics of Social Norms. Cambridge: Cambridge University Press.

BonJour, Laurence. 2008. "Can Empirical Knowledge Have a Foundation?" In Epistemology: An Anthology, eds. Ernest Sosa, Jaekwon Kim, Jeremy Fantl, and Matthew McGrath. New Jersey: John Wiley \& Sons, 10923. 
Buckland, Luke, and Clark Chinn. 2015. "Epistemology." In Encyclopedia of Science Education, ed. Richard Gunstone. Dordrecht: Springer Netherlands, 398-401.

DOI: https://doi.org/10.1007/978-94-007-2150-0_256.

Carter, J. Adam, and Clayton Littlejohn. 2021. This is Epistemology: An Introduction. New Jersey: John Wiley \& Sons.

Cooper, John. 1998. “al-Razi, Fakhr al-Din.” In Routledge Encyclopedia of Philosophy (Version 1 .0), ed. E. Craig. London: Routledge.

Cottingham, John. 1990. "Richard A. Watson, The Breakdown of Cartesian Metaphysics." Journal of the History of Philosophy 28(2): 296. DOI: https://doi.org/10.1353/hph.1990.0027.

"Creative | Definition of Creative by Merriam-Webster." https://www.merriam-webster.com/dictionary/creative (June 29, 2021).

Dabashi, Hamid. 2020. "Khwājah Naṣī al-Dīn al-Ṭūsī: The Philosopher/Vizier and the Intellectual Climate of His Times." In History of Islamic Philosophy. London: Routledge, 527-84.

"Daftar Kasus Ledakan Bom Di Indonesia 2 Dekade Terakhir." https://www.cnnindonesia.com/nasional/20210328150157-20623072/daftar-kasus-ledakan-bom-di-indonesia-2-dekade-terakhir (June 29, 2021).

"Definition of Constitutive." https://www.merriamwebster.com/dictionary/constitutive (June 29, 2021).

"Definition of Critical." https://www.merriamwebster.com/dictionary/critical (June 29, 2021).

"Descriptive | Definition of Descriptive by Merriam-Webster." https://www.merriam-webster.com/dictionary/descriptive (June 29, 2021).

Dodge, Bayard. 1962. Muslim Education in Medieval Times. Washington: The Middle East Institute. 
Durkheim, Emile. 1897. Le Suicide: Étude de Sociologie. New York, NY: F. Alcan.

Elder, Linda, and Richard Paul. 2020. Critical Thinking: Tools for Taking Charge of Your Learning and Your Life. Foundation for Critical Thinking.

Engel, Rafael J, and Russell K Schutt. 2014. Fundamentals of Social Work Research. USA: Sage Publications.

English, Oxford. 1976. "Oxford English Dictionary." Encyclopedia of Swearing: 334.

"Epistemology | Definition, History, Types, Examples, Philosophers, \& Facts | Britannica." https://www.britannica.com/topic/epistemology (June 29, 2021).

Esposito, John L. 2005. "Moderate Muslims: A Mainstream of Modernists, Islamists, Conservatives, and Traditionalists." American Journal of Islamic Social Sciences 22(3): 11-20.

DOI: https://doi.org/10.35632/ajis.v22i3.465.

al-Fârûqî, Isma'îl Râgî A. 1968. "The Self in Mu'tazilah Thought”. In EastWest Studies on the Problem of the Self, Springer, 87-107.

al-Fajjârî, Mukhtâr. 2005. Naqd al-Aql al-Islâmî 'inda Muhammad Arkoun. Beirut: Dâr al-Ṭâli'ah.

Fatoorchi, Pirooz. 2013. "On Intellectual Skepticism: A Selection of Skeptical Arguments and Țūsī's Criticisms, with Some Comparative Notes." Philosophy East and West 63(2): 213-50.

DOI: https://doi.org/10.1353/pew.2013.0023.

Fedyk, Mark, and Fei Xu. 2018. "The Epistemology of Rational Constructivism." Review of Philosophy and Psychology 9(2): 343-62. DOI: https://doi.org/10.1007/s13164-017-0372-1.

Feldstein, L. 1978. Homo Quaerens: The Seeker and the Sought. New York: Fordham. 
Ferrier, James Frederick. 1856. Institutes of Metaphysic: The Theory of Knowing and Being. Edinburg and London: W. Blackwood.

Foucault, Michel. 1970. "The Order of Things: An Archeology of Knowledge." AM Sheridan-Smith.

Foucault, Michel. 1972. The Archaeology of Knowledge: Translated from the French by AM Sheridan Smith. New York: Pantheon Books.

Foucault, Michel. 1970. The Order of Things, An Archaeology of the Human Sciences." New York: Pantheon Books 2: 46-49.

Foucault, Michel. 2020. Power/Knowledge. London: Routledge.

Friedkin, Noah E. 2004. "Social Cohesion." Annu. Rev. Sociol. 30: 409-25.

Gazalba, Sidi. 1973. Sistematika Filsafat. Jakarta: Bulan Bintang.

al-Ghazâlî, Abû Hâmid. 1964. Mizân al'Amal. Cairo: Dâr al-Ma'ârif.

al-Ghazâlî, Abû Hâmid. 1967. al-Munqidh min al-Dalal. Beirut: al-Maktabah al-Sha'biyah.

Geertz, Clifford. 1973. The Interpretation of Cultures. New York: Basic Books.

Geertz, Clifford. 1996. "After the Fact: Two Countries, Four Decades, One Anthropologist." History of The Human Sciences 9(4): 159-65.

Goffman, Erving. 1978. The Presentation of Self in Everyday Life. London: Harmondsworth.

Goffman, Erving. 2002. "Front and Back Regions of Everyday Life [1959]." In The Everyday Life Reader, ed. Ben Highmore. New York: Routledge, $50-57$.

Gopnik, Alison, and Elizabeth Bonawitz. 2015. "Bayesian Models of Child Development." Wiley interdisciplinary reviews: cognitive science 6(2): 7586.

DOI: https://doi.org/10.1002/wcs.1330.

Gordon, Matthew S. 2011. "The Great Caliphs: The Golden Age of the Abbasid Empire by Amira K. Bennison." International Journal of Middle East Studies 43(3): 572-3. 
Greco, John. 2017. "Introduction: What Is Epistemology." In The Blackwell Guide to Epistemology, eds. John Greco and Ernest Sosa. Oxford: Blackwell Publishers.

Griffel, Frank. 2007. "On Fakhr al-Dīn al-Rāzī's Life and the Patronage He Received." Journal of Islamic Studies 18(3): 313-44.

Guedon, Jean Claude. 1977. "Michel Foucault: The Knowledge of Power and the Power of Knowledge." Bulletin of the History of Medicine 51(2): 245-77.

Heck, Paul L. 2013. Skepticism in Classical Islam: Moments of Confusion. London and New York: Routledge.

Hery, Musnur. 2008. "Epistemologi Pendidikan Islam: Melacak Metodologi Pengetahuan Perguruan Tinggi Islam Klasik.” INSANIA: Jurnal Pemikiran Alternatif Kependidikan 13(3): 453-73.

Hilmy, Masdar. 2008. Islam Profetik: Substansiasi Nilai-Nilai Agama Dalam Ruang Publik. Yogyakarta: Kanisius.

Hilmy, Masdar. 2013a. Pendidikan Islam $\mathcal{E}$ Tradisi Ilmiah. Malang: Pustaka Madani.

Hilmy, Masdar. 2013b. "Whither Indonesia's Islamic Moderatism? A Reexamination on the Moderate Vision of Muhammadiyah and NU." Journal of Indonesian Islam 7(1): 24-48.

DOI: https://doi.org/10.15642/JIIS.2013.7.1.24-48.

Hirose, Iwao, and Jonas Olson. 2015. "Introduction to Value Theory." The Oxford Handbook of Value Theory: 1-9.

Hitchcock, David. 2017. "Critical Thinking as an Educational Ideal.” In On Reasoning and Argument, Springer, 477-97.

Hoodbhoy, Pervez. 1988. "They Call It Islamic Science.” The Herald.

Hoodbhoy, Pervez. 1991. Islam and Science: Religious Orthodoxy and the Battle for Rationality. London: Zed Books. 
al-Hujwirî, 'Alî ibn 'Uthmân. 1976. "The Kashf al-Mahjub.” Translated from the text of the Lahore edition compared with mss. in the India Office and British Museum by RA Nicholson. Luzaq and Company Ltd., London.

Iman, Fuji Nur, 2020. "Relationship of the Quran and Other Religious Scriptures: Studies on al-Muhaymin in Q.S. al-Mâidah 48." Ulul Albab: Jurnal Studi Islam 21(1): 86-103.

DOI: https://doi.org/10.18860/ua.v21i1.8714.

"Inquisitiveness | Meaning in the Cambridge English Dictionary." https://dictionary.cambridge.org/dictionary/english/inquisitiveness (June 29, 2021).

Iqbal, Mohammad. 2013. The Reconstruction of Religious Thought in Islam. Stanford University Press.

al-Jâbirî, Muhammad 'Âbid. 2000. Takwîn al-'Aql al-Arabî [Formation of Arab Reason]. Casablanca: Dâr al-Nashr al-Maghribiyya.

al-Jâbirî, Muhammad 'Âbid. 1991. Bunyah al-Aql al-Arabî. Dirâsah Taḥlîliyyah Naqdiyyah li Nuḍum al-Ma'rifah fî al-Thaqâfah al'Arabiyyah.

al-Jâbirî, Muḥammad 'Âbid. 2003. Formasi Nalar Arab (Kritik Tradisi Menuju Pembebasan dan Pluralisme Wacana Interreligius. Trans. Imam Khoiri. Yogyakarta: IrCiSoD.

al-Jâbirî, Muhammad 'Âbid. 1995. Naqd al-Aql al-Arabî III: al-'Aql al-Siyâsî al'Arabî, Muhaddadâtuhu wa Tajliyatuhu. Beirut: Markaz Dirâsât alWiḥdah al-'Arabiyyah.

Kamali, Mohammad Hashim. 2003. "Islam, Rationality and Science." Islam ES Science 1(1): 115-115.

Kamali, Mohammad Hashim. 2015. The Middle Path of Moderation in Islam: The Qur"anic Principle of Wasatiyyah. Oxford: Oxford University Press.

Kant, Immanuel et al. 1952. The Critique of Pure Reason, Translated by JMD Meiklejohn: The Critique of Practical Reason and Other Ethical Treatises, Translated by Thomas Kingsmill Abbott, W. Hastie; The Critique of 
Judgement, Translated by James Creed Meredith. Encyclopædia Britannica.

Kattsof, Louis O. 1996. Pengantar Filsafat. Yogyakarta: Tiara Wacana.

Kelly, Thomas. 2003. "Epistemic Rationality as Instrumental Rationality: A Critique." Philosophy and Phenomenological Research 66(3): 612-40.

Khan, Diwan Taskheer. 2017. "Mu'tazilaism: An Introduction to Rationality in Islam." International Journal of Engineering and Applied Sciences 4(10): 257359.

Kiswati, Tsuroya. 2015. Al Juwaini: Peletak Dasar Teologi Rasional dalam Islam. Jakarta: Erlangga.

Koesnoe, Moh. 1997. Pengantar Ke Arah Pemikiran Filsafat Hukum: Suatu Catatan Kuliah. Surabaya: Ubhara Press.

Kuhn, Thomas S. 2012. The Structure of Scientific Revolutions. Chicago: University of Chicago Press.

al-Kurdî, Râjị̣ 'Abd al-Hamîd. 1992. Naẓariyyah al-Ma'rifah Bayn al-Qur'ân wa al-Falsafah. Riyâd: Maktabah al-Muayyad.

Landesman, Charles. 2002. Skepticism: The Central Issues. Oxford: Blackwell Publishers.

Lane, Jan-Erik, and Hamadi Redissi. 2016. Religion and Politics: Islam and Muslim Civilisation. London: Routledge.

Lim, Bridget, and Aisha Khan. 2016. Avicenna: Leading Physician and Philosopher-Scientist of the Islamic Golden Age. The Rosen Publishing Group, Inc.

McDowell, John. 1998. "The Constitutive Ideal of Rationality: Davidson and Sellars." Crítica: Revista Hispanoamericana de Filosofía 30(88): 2948.

McGinn, Colin. 1975. "A Priori" and "A Posteriori" Knowledge." Proceedings of the Aristotelian Society New Series 76, 195-208. 
"Menag: Pengarusutamaan Moderasi Beragama Melalui Lembaga Pendidikan Sangat Strategis Kementrian Agama RI.” https://kemenag.go.id/read/menag-pengarusutamaan-moderasiberagama-melalui-lembaga-pendidikan-sangat-strategis-4x140 (June 29, 2021).

Mikhail, John. 2004. "Islamic Rationalism and the Foundation of Human Rights." PLURALISM AND LAW: Proceedings of the 20th IVR Congress 3: 61-70.

Moller, Arlen, and Edward Deci. 2014. "Intrinsic Motivation." In Encyclopedia of Quality of Life and Well-Being Research, ed. Alex C. Michalos. Dordrecht: Springer Netherlands, 3378-81.

DOI: https://doi.org/10.1007/978-94-007-0753-5_1532.

Moser, Paul K, and Arnold Vander Nat. 1978. "General Introduction, Human Knowledge-Its Nature, Origin and Limit." Human Nature: Classical and Contemporary Approaches.

Nasution, Harun. 1995. Islam Rasional: Gagasan Dan Pemikiran. Bandung: Mizan.

"Normative | Definition of Normative by Merriam-Webster." https://www.merriam-webster.com/dictionary/normative (June 29, 2021).

Nûr-ad-Dîn 'Abd-ar-Raḥmân Ibn-Aḥmad Ğâmî, and Edward H Whinfield. 1906. Lawâ'iḥ: A Treatise on Șûfism: Facsimile of an Old Ms. Royal Asiatic Soc.

Pahl, Raymond Edward. 1991. "The Search for Social Cohesion: From Durkheim to the European Commission." European Journal of Sociology/Archives Européennes de Sociologie/Europäisches Archiv für Soziologie 32(2): 345-60.

Paul, Richard, and Linda Elder. 2019. The Nature and Functions of Critical $\mathcal{E}$ Creative Thinking. Rowman \& Littlefield.

Pourjavady, Nasrollah. 2000. Nasīr Al-Dīn Tūsī: Philosophe et Savant Du XIIle Siècle. Institut français de recherche en Iran. 
Prasetia, Senata Adi, and Siti Firqo Najiyah. 2021. "The Revitalization of Education Character in The Pandemic Covid-19 Era.” TADRIS: Jurnal Pendidikan Islam 16(1): 95-110.

DOI: https://doi.org/10.19105/tjpi.v16i1.4029.

Qadir, Chaudhry Abdul. 1988. Philosophy and Science in the Islamic World. Croom Helm.

Qomar, Mujamil. 2005. Epistemologi Pendidikan Islam: Dari Metode Rasional Hingga Metode Kritik. Jakarta: Erlangga.

Rahman, Fazlur. 2009. Major Themes of the Qur'an. Chicago: University of Chicago Press.

"Ratio | Mathematics | Britannica". https://www.britannica.com/science/ratio (June 29, 2021).

al-Râzî, Muhạmmad ibn 'Umar Fakhr al-Dîn. 1984. Kitab al-Muhassal (Muhassal Afkâr al-Mutaqaddimîn wa al-Muta'akhkhirîn min al-Hukamâ' wa al-Mutakallimîn). Edited by H. Atay. Cairo: Maktabat Dâr alTurâth.

Redfield, Robert. 1955. "The Social Organization of Tradition." The Far Eastern Quarterly 15(1): 13-21.

Renima, Ahmed, Habib Tiliouine, and Richard J Estes. 2016. "The Islamic Golden Age: A Story of the Triumph of the Islamic Civilization.” In The State of Social Progress of Islamic Societies, Springer, 25-52.

Rescorla, Michael. 2013. "Rationality as a Constitutive Ideal." In A Companion to Davidson, eds. Ernie Lapore and Kirk Ludwig. John Wiley \& Sons, 472-88.

DOI: https://doi.org/10.1002/9781118328408.ch27.

Rhode, Deborah. 2006. In Pursuit of Knowledge: Scholars, Status, and Academic Culture. Stanford University Press.

Ringer, Fritz K. 1992. Fields of Knowledge: French Academic Culture in Comparative Perspective, 1890-1920. Cambridge: Cambridge University Press. 
Rowe, Alan J. 2004. “Creative Intelligence." Financial Times/Prentice Hall.

Rumi, Jalaluddin. 1994. "Masnavi Manavi." Amir Kabir Publiา cation, Tehran, Iran. p 222.

Runes, Dagobert D. 2001. The Dictionary of Philosophy. Citadel Press.

Ryan, Richard M, and Edward L Deci. 2000. "Self-Determination Theory and the Facilitation of Intrinsic Motivation, Social Development, and Well-Being." American psychologist 55(1): 68-78.

DOI: https://doi.org/10.1037/0003-066X.55.1.68.

Sabic-El-Rayess, Amra. 2020. "Epistemological Shifts in Knowledge and Education in Islam: A New Perspective on the Emergence of Radicalization amongst Muslims." International Journal of Educational Development 73: 102148.

DOI: https://doi.org/10.1016/j.ijedudev.2019.102148.

Scheibe, Erhard. 2001. "Between Rationalism and Empiricism." In Between Rationalism and Empiricism, Springer, 1-86.

"Science in Islam: "Curiosity Leads to Scientific Contributions"". https://tribune.com.pk/story/495077/science-in-islam\%E2\%80\%98curiosity-leads-to-scientific-contributions\%E2\%80\%99 (June 29, 2021).

Sen, Amartya Kumar. 1999. "Democracy as a Universal Value." Journal of democracy $10(3): 3-17$.

Smith, David Eugene. 1923. 1 History of Mathematics...: General Survey of the History of Elementary Mathematics. Ginn.

Smith, Wilfred Cantwell. 1971. "The Study of Religion and the Study of the Bible". Journal of the American Academy of Religion 39(2): 131-40.

Smith, Wilfred Cantwell. 1989. "Scripture as Form and Concept: Their Emergence for the Western World." Rethinking Scripture: Essays from a comparative perspective: 29-57. 
Society for the Diffusion of Useful Knowledge (Great Britain). 1836. 5 Penny Cyclopaedia of the Society for the Diffusion of Useful Knowledge. C. Knight.

Steffe, Leslie P, and Jerry Edward Gale. 1995. Constructivism in Education. Psychology Press.

Steup, Matthias, John Turri, and Ernest Sosa. 2013. Contemporary Debates in Epistemology. John Wiley \& Sons.

Suharo, Babun, et.al. 2019. Moderasi Beragama: dari Indonesia untuk Dunia. Yogyakarta: LKiS.

Suradi, Ahmad, Qolbi Khoiri, Nilawati Nilawati, Nopian Gustari. 2021. "Designing the Pesantren Curriculum to Counter Radicalism: Study on Pondok Pesantren Wali Songo Ngabar Ponorogo." Ulul Albab: Jurnal Studi Islam 22(1): 49-68.

DOI: https://doi.org/10.18860/ua.v22i1.11212.

Sunhaji, Sunhaji. 2017. "Between Social Humanism and Social Mobilization: The Dual Role of Madrasah in the Landscape of Indonesian Islamic Education." Journal of Indonesian Islam 11(1): $125-$ 44.

DOI: https://doi.org/10.15642/JIIS.2017.11.1.125-144.

Tahko, Tuomas E. 2011. "A Priori and a Posteriori: A Bootstrapping Relationship." Metaphysica 12(2): 151-64.

DOI: https://doi.org/10.1007/s12133-011-0083-5.

Tamer, Georges. 2015. Islam and Rationality: The Impact of al-Ghazālī. Papers Collected on His 900th Anniversary. Vol. I. Brill.

Thomson, Arthur. 1964. "The Philosophy of JF Ferrier." Philosophy 39(147): $46-62$.

Walker, Caren M, Alison Gopnik, and Patricia A Ganea. 2015. "Learning to Learn from Stories: Children's Developing Sensitivity to the Causal Structure of Fictional Worlds." Child development 86(1): 310-18.

DOI: $10.1111 /$ cdev.12287. 
Webster, Peter R. 1990. "Creativity as Creative Thinking." Music Educators Journal 76(9): 22-28.

Weiss, Bernard. 1978. "Interpretation in 1slamic Law: The Theory of Ijtihâd." The American Journal of Comparative Law 26(2): 199-212.

Wentworth, George, David Eugene Smith, and Herbert Druery Harper. 1922. Fundamentals of Practical Mathematics. Ginn.

Wijaya, Aksin. 2014. Satu Islam, Ragam Epistemologi. Yogyakarta: IRCISOD.

Wiktorowicz, Quintan, and Karl Kaltenthaler. 2006. "The Rationality of Radical Islam.” Political Science Quarterly 121(2): 295-319.

Williamson, Timothy. 2013. "Between A Priori and A Posteriori Knowledge?" The a priori in philosophy 291.

Woleński, Jan. 2004. "The History of Epistemology." In Handbook of Epistemology, Springer, 3-54. 